\title{
John Stuart Mill: Law, Morality, and Liberty
}

DOI:

$10.1017 / \mathrm{S} 1479244316000160$

\section{Document Version}

Accepted author manuscript

Link to publication record in Manchester Research Explorer

\section{Citation for published version (APA):}

Jones, H. S. (2018). John Stuart Mill: Law, Morality, and Liberty. Modern Intellectual History, 15(3), 879-91. https://doi.org/10.1017/S1479244316000160

\section{Published in:}

Modern Intellectual History

\section{Citing this paper}

Please note that where the full-text provided on Manchester Research Explorer is the Author Accepted Manuscript or Proof version this may differ from the final Published version. If citing, it is advised that you check and use the publisher's definitive version.

\section{General rights}

Copyright and moral rights for the publications made accessible in the Research Explorer are retained by the authors and/or other copyright owners and it is a condition of accessing publications that users recognise and abide by the legal requirements associated with these rights.

\section{Takedown policy}

If you believe that this document breaches copyright please refer to the University of Manchester's Takedown Procedures [http://man.ac.uk/04Y6Bo] or contact uml.scholarlycommunications@manchester.ac.uk providing relevant details, so we can investigate your claim.

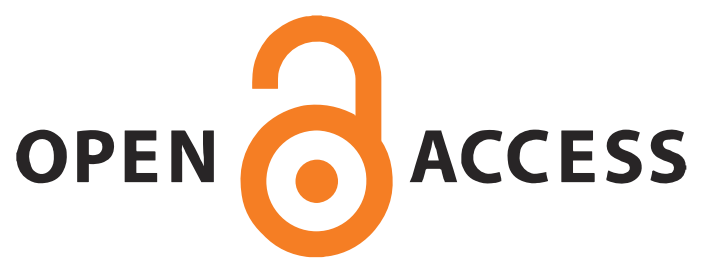




\section{John Stuart Mill: Law, Morality, and Liberty}

\section{H.S. Jones}

Gregory Claeys, Mill and Paternalism (Cambridge: Cambridge University Press, 2013)

Georgios Varouxakis, Liberty Abroad: J.S. Mill on International Relations (Cambridge: Cambridge University Press, 2013)

Ever since the resurgence of the sub-discipline in the 1960s, the foremost achievements of the history of political thought have dealt with the early modern period. The classics of the genre - Laslett's edition of Locke, Pocock's Machiavellian Moment, Skinner's Foundations have all dealt with that period, and it is hard to think of any works on the nineteenth century that have quite the same stature. Of all the canonical political thinkers, John Stuart Mill is perhaps the one who has proved resistant to the contextualist method. There is a vast literature on Mill, and many historians have written penetratingly about him - Stefan Collini, William Thomas, Donald Winch - but there has hitherto been no historically grounded study of his thought to rival, say, John Dunn on Locke or Skinner on Hobbes, or even a host of learned monographs. Before Varouxakis's book, no study of Mill had been published in Cambridge University Press's flagship series in intellectual history, "Ideas in Context". But all that has changed. In these two works, published more or less concurrently, 
we have two triumphs for contextualism. They demonstrate in impressive detail just why it matters in reading Mill to get the history right.

They do so in quite distinct ways. Georgios Varouxakis takes a subject - international relations - on which Mill did not write a book, but on which he nevertheless published extensively in newspapers and periodicals, including some pieces, such as "A few words on non-intervention", which have been much anthologised. Varouxakis has, first of all, undertaken a profound and exhaustive scholarly service in locating and bringing into focus the whole range of Mill's writings on questions of law and morality in international relations, on war and peace and empire. It is important to emphasise that these are dispersed across many different volumes in the Collected Works, which reflects the fact that "international political thought" - a field that flourishes today - scarcely existed at the time when that project was planned. ${ }^{1}$ But Varouxakis never falls victim to the "myth of coherence". He shows that recent commentators and anthologisers have often misunderstood what he was saying by presenting his texts as if they were responding to questions that were recognisably the same as ours. Thus he shows in Chapter 1 that Michael Walzer's discussion of Mill in his Just and Unjust Wars is misleading because Walzer treats

\footnotetext{
${ }^{1}$ The writings on India are brought together in volume XXX, and those on Ireland and the Empire in volume VI. But several of the key articles that Varouxakis relies on appear in volume XXI, Essays on Equality, Law, and Education: these include "A few words on non-intervention", "The contest in America" and "Treaty obligations". Another key article appears in volume XX, Essays on French History and Historians ("Vindication of the French Revolution of February, 1848"). Varouxakis also makes intensive use of the Later Letters (volumes XIV-XVII), the Newspaper Writings (volumes XXI to XXV), and the Public and Parliamentary Speeches (volumes XXVIII to XXIX). All references to Mill's work in this article are to the relevant volume of The Collected Works of John Stuart Mill, ed. John M. Robson, 33 vols (London, 1963-91), henceforth cited as CW.
} 
"A few words on non-intervention" as if it were written at the same time as On Liberty, which was not that case. On Liberty - written a few years previously - was published in February 1859, while "A few words on non-intervention" was published in December of the same year and had not even been conceived at the beginning of October. So concerns about the relations of the individual and the community were not at the forefront of Mill's mind when he wrote "A few words". Rather, Mill's correspondence suggests that in the later months of 1859 the issue that concerned him most was the British response to the wars of Italian unification - even though Mill barely alludes to that context in the text itself. ${ }^{2}$ Varouxakis develops this interpretation in full in Chapter Four, and it constitutes an exemplary model of how historical evidence can inform textual interpretation.

Varouxakis has accomplished something very striking. While Mill's political activism is well known, the standard studies of his political thought and his life have really given very little sense of his standing as a foreign policy intellectual. Yet Varouxakis demonstrates what a key role Mill played in challenging and shaping opinion on a number of major issues in international politics. These included the American Civil War: Mill's sympathy for the cause of the Union is familiar, but no-one has previously demonstrated what a leading role he played in mobilising British opinion. Not only did he publish two key articles - one in his own name, so lending authority to its arguments - but he was also instrumental in encouraging the Irish economist John Elliot Cairnes to publish his lectures on slavery in the form of a book, The Slave Power, rather than burying them in the form of periodical articles. ${ }^{3}$ Equally,

\footnotetext{
${ }^{2}$ Varouxakis, Liberty Abroad, 6-8.

${ }^{3}$ Varouxakis, Liberty Abroad, 154-8, and Georgios Varouxakis, “'Negrophilist' crusader: John Stuart Mill on the American Civil War and Reconstruction", History of European Ideas 39 (2013), 729-54.
} 
almost a decade later, Mill was pre-eminent in arguing against public enthusiasm for war with Russia over the denunciation of the Black Sea Clauses in $1870 .^{4}$

Mill's writings on empire in general and on India in particuar are now the subject of a rich historiography. ${ }^{5}$ Varouxakis makes an important intervention in that literature too, but perhaps his major contribution is to show that Mill's thoughts on empire are distorted when they are not understood in the context of his much wider body of writing on war, peace, and international politics. One illustration will suffice. Mill's imperialism has led to the accusation that he was a racist. ${ }^{6}$ Varouxakis has been influential in trying to refute that interpretation of Mill's liberal imperialism. ${ }^{7}$ But this case is much strengthened by what Mill had to say about a range of other issues in international politics, and not least the American Civil War. He was not just a leading campaigner - he used the word "crusader" - on the side of the North, but he very specifically identified slavery as the fundamental issue. British newspapers such as the Standard, responding to Mill, raised the spectre of a slave rebellion by "a race perhaps the most ignorant, excitable, and licentious on the face of the earth"; the

\footnotetext{
${ }^{4}$ Varouxakis, Liberty Abroad, 48-71.

${ }^{5}$ Important contributions include Jennifer Pitts, A Turn to Empire: The Rise of Imperial Liberalism in Britain and France (Princeton, 2009), chapter five; Stephen Holmes, “Making sense of liberal imperialism”, in Nadia Urbinati and Alex Zakaras (eds), J.S. Mill"s Political Thought: A Bicentennial Reassessment (Cambridge, 2007), 319-46; Uday Singh Mehta, Liberalism and Empire: A Study in Nineteenth-Century British Liberal Thought (Chicago, III., 1999).

${ }^{6}$ The most vocal advocate of this view is David Theo Goldberg, "Liberalism"s limits: Carlyle and Mill on "The Negro Question", in Bart Schultz and Georgios Varouxakis (eds), Utilitarianism and Empire (Oxford, 2005), 125-
} 35.

7 For example, Georgios Varouxakis, “John Stuart Mill on race”, Utilitas 10 (1998), 17-32. 
prospective victims of the "outrages" that would follow being "English ladies and children". 8 Against this view, Mill was staunch in denouncing and mobilising British opinion against "the most odious form of unjust dominion which ever existed". ${ }^{9}$

While Varouxakis expands our sense of the range of Mill's interests by focusing on his more ephemeral writings, Gregory Claeys's new book, Mill and Paternalism, makes a different kind of intervention. At its heart is a highly revisionist reinterpretation of On Liberty, one that works by taking seriously those of Mill's pronouncements and convictions that jar most with what we today assume that he must have intended to say. Above all, it asserts that we have to take seriously Mill's lifelong commitment to the cause of population control. It is well known that Mill, as a young man of seventeen, was arrested by the police (although not charged) for distributing some handbills prepared by Francis Place to advocate artificial birth control to the working class. The suspicion that Mill was an advocate of "obnoxious checks" on population was the reason for Gladstone's decision to withhold his subscription to a public memorial to Mill. ${ }^{10}$ But, Claeys contends, because Mill learnt from his early experience to avoid public identification with birth control, the extent of his continuing commitment to the cause has been seriously overlooked in Mill scholarship. Donald Winch has written that "Half a century after he had been arrested for distributing birth control literature, Mill continued to believe that restraining the Malthusian devil was essential to

\footnotetext{
${ }^{8}$ Quoted by Varouxakis, “'Negrophilist"” crusader”, 736. For Mill”s reference to a “crusade”, 731.

9 Quoted by Varouxakis, “'Negrophilist'” crusader”, 738.

10 John Morley, The Life of William Ewart Gladstone (London, 1922) II, 151-2.
} 
any prospect for a permanent rise in working-class living standards" ${ }^{11}$ But no-one before Claeys has tried to tease out how fundamental his neo-Malthusian commitments were to his social philosophy, and not least to his feminism.

It is worth dwelling for a moment on Claeys's method, and on the kind of evidence he uses to press his case. He maintains that Mill often enough indicated the importance he attached to marriage restraint, but that this concept "is simply not on our mental map, because it lies outside the spectrum of liberalism we accept. Accordingly we do not 'see' it in the text, in manifest defiance of Mill's intent. We make Mill 'liberal' by rendering invisible his iliberal themes, in a manner not unlike the old Stalinist erasing of unpersons from pictures." ${ }^{12}$ This may be an over-statement, not least because books purporting to demonstrate Mill's secret authoritarianism are sufficiently numerous to constitute a distinct academic genre. ${ }^{13}$ Still, there is an important methodological point here. Claeys lays down the excellent precept that we should pay attention to Mill's pronouncements about the validity of legal restrictions on the right to marry precisely because they are the kind of thing we would not expect from the pen of an archetypal mid nineteenth-century liberal. It is certainly the case that when, in On Liberty, Mill sets out to defend his view that "owing to the absence of any recognised general principles, liberty is often granted where it should be withheld, as well as

11 Donald Winch, Wealth and Life: Essays on the Intellectual History of Political Economy in Britain, 1848-1914 (Cambridge, 2009), 64.

12 Claeys, Mill and Paternalism, 177.

13 See notably Maurice Cowling, Mill and Liberalism (Cambridge, 1963; 2nd edn 1990); Shirley Robin Letwin, The Pursuit of Certainty: David Hume, Jeremy Bentham, John Stuart Mill, Beatrice Webb (Cambridge, 1965); Joseph Hamburger, John Stuart Mill on Liberty and Control (Princeton, 1999); and Linda Raeder, John Stuart Mill and the Religion of Humanity (Columbia, 2002). 
withheld where it should be granted", the examples he cites of the former are wholly connected with "family relations". Here he maintains the right of the state to intervene to ensure that parents fulfil their duties towards their children, including the duty to provide an education. But he also, more controversially from today's perspective, defends the laws imposed by continental states such as Bavaria which forbade marriage where the couple could not demonstrate that they had the means to support a family. ${ }^{14}$ The text of On Liberty does not quite demonstrate that Mill intended this as a positive proposal. What he says is that for states to restrict the right to marry in this way would not be an infringement of the liberty principle; and, equally, that this is an issue on which it is legitimate for public opinion to bear down quasi-coercively on those who give birth to children they cannot support. Still, Claeys assembles impressive evidence from other texts, including authoritative and carefully worded expositions of Mill's ideas such as Principles of Political Economy, to show that Mill was indeed committed to enforcing marriage restraint, initially by means of public opinion but perhaps by legislative means too. ${ }^{15}$

Claeys makes a further argument on the basis of this textual evidence. He maintains that contrary to what almost all commentators have thought, it shows that Mill saw the family, and not the individual, as the basic unit of society. Why is this? Because actions which would be self-regarding if performed by a single person would not be if performed by a married person who thereby become incapable of carrying out his or her parental obligations. "The duties we owe chiefly to our spouses and children, then more faintly to other relatives, are actually integral to understanding how the 'harm' principle works." Our vices become

\footnotetext{
14 John Stuart Mill, On Liberty, in Essays on Politics and Society Part 1, CW XVIII: 301-5.

${ }^{15}$ For example, John Stuart Mill, Principles of Political Economy Bk II ch xiii, CW II, 370-2.
} 
punishable when we cannot afford them at the same time as meeting our "distinct and assignable" obligations to our dependants. And the implication of that is clear for Claeys. Once the familial context is grasped, the sphere of liberty is much wider for the wealthy than it is for the poor. Hence "Mill's famous liberty principle ... is hemmed in to an astonishing degree by a class context" ${ }^{16}$

That is indeed an interesting and potentially far-reaching argument. It is very different from the familiar argument against the negative concept of freedom that whereas the rich man and the poor man might each enjoy the formal freedom to own a yacht, that freedom is a great deal more real for the former than for the latter. Claeys's point is that Mill's harm principle allows (legal or moral) coercion to be used against the poor man for conduct which would not be punishable if performed by a rich man. It is therefore highly inegalitarian in its implications. Yet Claeys also maintains, as one of the central themes of the book, that Mill had a deep commitment to equality. Exactly how these two arguments are reconciled remains something of a puzzle.

One aspect of Mill's egalitarianism that is particularly well known is his commitment to women's emancipation, and one of the most striking and persuasive arguments in Claeys's book is that there was a direct connection between Mill's Malthusianism and his feminism. Indeed, he suggests that by the time he wrote On Liberty Mill's position on birth control might more properly be termed "maternalism". ${ }^{17}$ On the one hand, the emancipation of women would lead to a louder voice for women in shaping decisions about family size, and Mill believed that this would tend to stem the problem of over-population. But conversely,

\footnotetext{
${ }^{16}$ Claeys, Mill and Paternalism, 179.

17 Claeys, Mill and Paternalism, 185.
} 
prudential control of family size was a prerequisite for women's emancipation. Whether the parents could afford a large family was only a part of the issue. A "much more important consideration still", Mill thought, was "the perpetuation of the previous degradation \& slavery of women, no alteration in which can be hoped for while their whole lives are devoted to the function of producing \& rearing children". Hence "the limitation of the number of children would be in my opinion absolutely necessary to place human life on its proper footing, even if there were subsistence for any number that could be produced". ${ }^{18}$

There is one major problem with Claeys's book, and it is signalled by the title. Claeys makes the case that Mill was a paternalist, but he does so by conflating paternalism with interventionism. Claeys is well aware of the distinction, and makes the point several times. ${ }^{19}$ He cites numerous definitions of paternalism from the extensive modern literature on Mill and paternalism, but they practically all amount to something like this: in H.L.A. Hart's words, paternalism is "the protection of people against themselves". ${ }^{20}$ Sometimes Claeys recognises clearly that intervention per se does not imply paternalism; but elsewhere he unhelpfully clouds the issue. A flagrant example occurs in the Introduction. Here Claeys cites as instances of paternal interference that Mill allowed those cases of "positive acts for the benefit of others" that, he argues in On Liberty, individuals could "rightfully be compelled to perform", such as paying taxes, serving on a jury, giving evidence in court, and so on. This is an extraordinary argument. To compel an individual to serve on a jury is undoubtedly an abridgement of his or her negative liberty. But who has ever tried to justify these kinds of

\footnotetext{
${ }^{18}$ Mill to Professor Green, 8 April 1852, CW XIV, 88-9, quoted by Claeys, Mill and Paternalism, 185-6.

${ }^{19}$ Claeys, Mill and Paternalism, 92, 196.

${ }^{20}$ Claeys, Mill and Paternalism, 51-2.
} 
compulsion on paternalistic grounds, that is, as instances of the state's right to intervene to prevent an individual doing harm to himself or herself? Mill explicitly says that he understands these cases to be justified by benefit to others, and it is quite unclear how this can usefully be analysed as a paternalistic argument. ${ }^{21}$

We can see why it is important to Claeys to lay claim to the concept of paternalism when he proceeds to discuss the role Mill hoped that feminism would play in altering power relations within the family and thus leading to a prudential limitation on family size. Claeys writes: "Maternalism becomes the antidote to paternalism: paternalism starts with the problem of uncontrolled paternity, with the blame lying chiefly with reckless men and ends with controlled maternity, chiefly instigated by thoughtful and prudent women."22 This is a nice line, but it depends on the unproven claim that Mill's argument for controls on marriage was paternalistic in character. Mill professed to be defending the rights of children, but he also believed that limitation of family size was the route to improved living standards for the working class. For Claeys, this latter argument is the paternalistic one: working-class couples could voluntarily limit family size, but they needed help to understand their own best interests. That is a key assumption, on which the coherent elegance of the book really depends. But in fact it is not difficult - even for the reader confined to the data supplied by Claeys - to assemble copious evidence to suggest that the benefits to be derived from population restraint were, in Mill's mind, collective much more than individual. These benefits were varied, but included higher average wages and environmental protection. ${ }^{23}$ If

\footnotetext{
${ }^{21}$ Claeys, Mill and Paternalism, 49.

${ }^{22}$ Claeys, Mill and Paternalism, 185.

${ }^{23}$ Both cited by Claeys, Mill and Paternalism, 186.
} 
population increase outran the increase of capital, real wages would be depressed; but if population increase could be restrained below the rate of increase of capital, rising real wages would hold out the prospect of "a well-paid and affluent body of labourers". At the same time, Mill argued (in his famous chapter "Of the stationary state"), the advanced countries had already reaped all the advantages demographic increase could supply in terms of "co-operation" and "social intercourse"; further demographic pressure would harm the quality of life by removing the possibility of "solitude in the presence of natural beauty and grandeur". ${ }^{24}$

It is revealing to see how Claeys answers this point. Towards the end of Chapter Three, he tells us: "On Liberty nonetheless defends this example [familial responsibility] as the strongest case for paternalism in a civilised society." Claeys immediately asks whether this is "strictly speaking" paternalism, if the interference is intended to benefit not chiefly the parents concerned, but primarily their children and secondarily the labouring class as a whole. That is precisely the point. So what evidence does Claeys adduce to support his argument? He invokes a passage from "The Claims of Labour", an article Mill published in the Edinburgh Review in 1845. There Mill writes of those continental European governments that combined "paternal care" with "paternal authority". Those states imposed severe restrictions on marriage, for the benefit of the people themselves. "Far from allowing the working classes, then, to suffer 'the natural consequences of their mistakes in life', Mill wished 'society to guard against the mistakes, by prevention or punishment'. He indisputably considered such legislation as paternalist. ${ }^{25}$

\footnotetext{
${ }^{24}$ Mill, Principles, CW III, 752-7.

${ }^{25}$ Claeys, Mill and Paternalism, 196.
} 
It is important to challenge Claeys's use of evidence here, because it is seriously flawed. The passage from which Claeys quotes here reads: "There are but two modes of social existence for human beings: they must be left to the natural consequences of their mistakes in life; or society must guard against the mistakes, by prevention or punishment." ${ }^{26}$ Claeys quotes Mill as if Mill thought the latter position was obviously preferable, but of course that is the opposite of the truth. The article in question was written to challenge the new paternalism towards the poor which Mill found on both Left and Right. Mill said as much when he described the article he had in mind to the editor of the Edinburgh Review, Macvey Napier: "It appears to me that along with much of good intention, \& something even of sound doctrine, the speculations now afloat are sadly deficient, on the whole, in sobriety \& wisdom - forgetful, in general, of the lessons of universal experience, \& of some of the most fundamental principles which one did think had been put for ever out of the reach of controversy by Adam Smith, Malthus, \& others. The general tendency is to rivet firmly in the minds of the labouring people the persuasion that it is the business of others to take care of their condition, without any self control on their own part - \& that whatever is possessed by other people, more than they possess, is a wrong to them, or at least a kind of stewardship, of which an account is to be rendered to them." ${ }^{27}$ So Mill certainly recognised that there were European states that imposed legal restrictions on marriage and that they did so for paternalistic reasons. But in this text he showed no sympathy for those legal restrictions and he fundamentally objected to the paternalistic intentions. Claeys is simply wrong to suggest

\footnotetext{
${ }^{26}$ Mill, “The claims of labour" [1845] CW IV: 374.

27 Mill to Macvey Napier, 9 November 1844, CW XIII: 643-4.
} 
that what we find in "The Claims of Labour" is "a very robust form" of paternalism. ${ }^{28}$ Mill describes paternalism and rejects it.

There is, in fact, a decisive passage on this precise point in Book II Chapter xiii of the Principles of Political Economy. Mill develops the argument that what is above all needed for the triumph of prudence among working-class families is the ascendancy of a moral conviction that such prudential restraint would be desirable. He notes that "We are often told that the most thorough perception of the dependence of wages on population will not influence the conduct of a labouring man, because it is not the children he himself can have that will produce any effect in generally depressing the labour market." Population restraint is thus a public good. Mill draws the comparison with the causes that prevent desertion of the army by soldiers in the midst of battle: "it is the disgrace which naturally and inevitably attends on conduct by any one individual, which if pursued by a majority, everybody can see would be fatal." ${ }^{29}$ To the extent that this was Mill's primary and considered account of the benefits to be derived from prudential restraint among the working class, then (pace Claeys) his case for the intervention either of public opinion or of the legislator was not a paternalist one at all.

The unnecessary confusion generated by the way in which Claeys foregrounds the concept of paternalism should not be allowed to detract from the fundamental insights his book offers. Not only does he offer the fullest recent account of Mill's attitude towards state intervention and his movement towards a kind of socialism, but he also, crucially, places the emancipation of women at the heart of Mill's theory of social progress. He demonstrates

\footnotetext{
${ }^{28}$ Claeys, Mill and Paternalism, 197.

${ }^{29}$ Mill, Principles, CW II: 370-1
} 
conclusively how important the question of birth control remained for Mill, as the key both to any significant improvement in the living standards of the working classes and to the emancipation of women from enslavement to childbirth and child-rearing. Feminism, Claeys rightly insists, "was not something simply tacked onto Mill's liberalism: it represented the development of his general theory of progress". ${ }^{30}$

\section{Mill as Public Moralist}

Where do these two books leave the state of Mill scholarship? One of the most important developments in Mill studies over the last twenty-five years or so has been the "ethical turn", in which Mill's role as a "public moralist" is at least as important as his role as an abstract theorist. ${ }^{31}$ Both Varouxakis and Claeys have illuminated in new ways Mill's quest to challenge the moral consensus of his time, not so much in order to defend individual freedom against this moral consensus (although he did that too), but primarily in order to shape a new and improved set of moral norms. They both have important things to say about the relationship between law and morals in Mill's thought.

This subject has a history, of course. In the Hart-Devlin debate on the legal enforcement of morality in the wake of the Wolfenden Report of 1957, Mill was invoked for supposedly

${ }^{30}$ Claeys, Mill and Paternalism, 41.

${ }^{31}$ Key works include Bernard Semmel, John Stuart Mill and the Pursuit of Virtue (New Haven, 1984); Stefan Collini, "The idea of 'character' in Victorian political thought", Transactions of the Royal Historical Society 35 (1985), 29-50; Stefan Collini, Public Moralists: Political Thought and Intellectual Life in Britain, 1850-1930 (Oxford, 1991); and Bruce L. Kinzer, Ann P. Robson and John M. Robson, A Moralist in and out of Parliament: John Stuart Mill at Westminster, 1865-1868 (Toronto, 1992). 
advocating a strict separation between law and morality: certain kinds of sexual behaviour might be violations of morality but should only come within the purview of the law to the extent that they involved harm to others. Alan Ryan and others have long ago demonstrated that this is a fundamental misunderstanding: the harm principle defines the proper scope of positive morality as well as of law, according to Mill. ${ }^{32}$ Nevertheless, the practical place of positive morality in Mill's thought remains little studied; yet it is fundamental.

Varouxakis's work is incisive here. He demonstrates that Mill fully shared in the Victorian "discovery" of international law in the 1860s, especially in response to the American Civil War and a range of legal issues it threw up, notably those arising from the Alabama dispute. In his Inaugural Address as Rector of the University of St Andrews (1867) he insisted that international law was a subject that "every citizen" should know, and that it should therefore be taught in every university and should "form part of all liberal education". ${ }^{33}$ Mill shared John Austin's belief, derived from the command theory of law, that international law was not law in the strict sense of the word, since it did not issue from the commands of a sovereign. Instead it should be understood as positive international morality, or the actually existing moral code governing questions of how states should behave towards each other. Neither for Austin nor certainly for Mill did this mean that international law was any the less important than other branches of law. But the task of changing positive morality was a more challenging one than the task of achieving law reform. This was a problem that Mill

\footnotetext{
32 Varouxakis, Liberty Abroad, 25. The locus classicus is Alan Ryan, The Philosophy of John Stuart Mill, 2nd edn (Basingstoke, 1987), ch xiii.

33 J.S. Mill, Inaugural Address delivered to the University of St Andrews [1867], CW XXI: 246.
} 
confronted in particular in addressing the question of whether treaty obligations should be regarded as perpetual.

This issue first arose, for Mill, in connection with the French Revolution of 1848, of which he was an enthusiastic supporter. The Provisional Government declared its policy of support for oppressed nationalities, and this was widely denounced as a violation of the "law of nations", not least because it would overturn the settlement agreed at the Congress of Vienna. In his "Vindication of the French Revolution of February 1848", Mill took issue with this criticism. He began with an Austinian insistence that to call the law of nations law was "a misapplication of terms": it should more properly be understoold as "a set of international usages". He went on to ask - and this is crucial: "Now, are international usages the only kind of customs which, in an age of progress, are to be subject to no improvement? Are they alone to continue fixed, while all around them is changeable?" In the case of international law there was no procedure to achieve law reform: rather, the only way of changing internaional morality was to violate existing rules. ${ }^{34}$

Mill's highest-profile engagement with the question of the sanctity of treaty obligations occurred in the context of the war scare of 1870-1 following Russia's denunciation of the Black Sea clauses of the Treaty of Paris of 1856. Russia had been forced to accept the neutralisation of the Black Sea following her defeat in the Crimean War, but took advantage of the outbreak of the Franco-Prussian War to abrogate those clauses. British opinion, while commonly acknowledging that the clauses were difficult to justify by themselves except as the straightforward exaction of a superior military power, also held that British honour was at stake, and that Britain must be willing to go to war to enforce these treaty obligations just

\footnotetext{
${ }^{34}$ Varouxakis, Liberty Abroad, 23.
} 
because they were treaty obligations. Those who held this opinion included some of Mill's former allies, such as Leonard Courtney, who had collaborated with Mill over the American Civil War and was now a leader-writer on The Times. Mill was the foremost campaigner against the push for war, notably in a series of letters to The Times in November 1870 . He told Courtney: "The fons et origo mali is the great error of concluding treaties in perpetuity, instead of only for a term of years."

This was a key issue for Mill: treaties that were concluded in perpetuity seemed to foreclose any possibility of progress in positive international morality, and hence, as he had put it back in April 1849, to dictate that international usages, unlike all other customs, would be shielded from any form of improvement. Imposing a term of years was a way of ensuring that treaty obligations could be kept sacrosanct; whereas perpetual obligations would inevitably, sooner or later, be broken. Mill was explicit in drawing the connection with other forms of perpetual settlement - 'a dynasty, an irrevocable law, a particular disposition of public or private property' - which mankind now recognised would inevitably require revision. ${ }^{35}$

Mill was alluding here, among other things, to an issue that concerned him for practically the entirety of his public life: that of the sanctity of perpetual endowments, or the permanent property of corporate bodies or trusts. This was a question of great prominence in Victorian political controversy, in the context of a range of thorny and disputed problems including church disendowment, university reform, and the reorganisation of the major public schools and a host of endowed grammar schools. Mill showed a sustained interest in it across the entire span of his lengthy literary career.

\footnotetext{
${ }^{35}$ Varouxakis, Liberty Abroad, 52.
} 
Mill's philosophic radical background disposed him to be suspicious of endowments, and as he was well aware, thinkers whom he greatly admired, such as Turgot, had been devastating in their denunciations of the social and economic harm caused by endowed foundations. But Mill himself came to formulate a more complex position. He accepted that endowments were valuable on pluralistic grounds: since the mainspring of progress is diversity, it is desirable that public goods such as education should be provided by a range of agencies, and not simply by the state. Endowments were a means of sustaining that diversity of provision. ${ }^{36}$ But if endowments were accepted as socially useful, then it followed that founders' intentions should be respected, since no-one would leave property for a purpose if that disposition could be over-ridden in favour of whatever purpose the government of the day favoured. But that did not in the least imply that founders should have some kind of perpetual control over the disposition of their property. This was a mere superstition - and by the time he addressed the question at length in 1869 , he regarded it (surely prematurely) as exploded by the disendowment of the Irish church. Perpetual social institutions were simply untenable in an age which believed in the possibility of social and moral progress. Mill's solution - as in the case of treaty obligations - was to establish a principle that founders' intentions should be respected for a term of years: "no more than two or three generations" was his suggestion. ${ }^{37}$

Claeys's subject can also be analysed through the lens of positive morality. Mill was clear that marriage size was profoundly shaped by the state of opinion - or, in other words, by positive morality. Currently, public opinion among the working class acted as a stimulus to

\footnotetext{
${ }^{36}$ Mill, Autobiography, CW I: 128.

37 Mill, 'Endowments' [1869], CW V: 621.
} 
“over-ingulgence' and hence to large families, since the ability to father many children was regarded as the primary proof of masculine virtue. But once "the labouring class" was generally persuaded that the main cause of their poverty was over-population, which had the effect of depressing wages, the desirability of limiting family size would be readily accepted. The effective diffusion of that opinion would be sufficient to make "self-control" the norm. Recalcitrants would be few: only "those ... who were in the habit of making light of social obligations generally". At that point, it might be appropriate to use the law to coerce the recalcitrant minority, "just as in many other cases of the progress of opinion, the law ends by enforcing against recalcitrant minorities, obligations which to be useful must be general, and which, from a sense of their utility, a large majority have voluntarily consented to take upon themselves." ${ }^{38}$

So Mill contemplated the possibility of legal restraint, and he certainly recognised its legitimacy; but it was never more than tangential to his solution to the population problem. Legal interference with marriage could not effectively change the mores of the working class; and once those mores had changed, legal interference would be at most of marginal importance. And, he added, it might not be necessary at all, since the emancipation of women would, he thought, decisively shift working-class opinion in the direction of marital restraint. The problem of population was fundamentally rooted in the positive morality that prevailed among the working class; and its solution depended critically on improving that moral code. Feminism was a key part of Mill's strategy for achieving that moral change. If Mill as at all well disposed towards legal restraints on marriage, it was less because he thought they would be causally efficient than because they consecrated a moral truth that

38 Mill, Principles, CW II: 370-2. 
the act of starting a family was a social act affecting the interests of others. It should therefore be subject to moral pressure. This argument was comparable to Mill's case for open voting: this might open up the possibility of bribery and improper influence on voters, but it also signalled the important truth that the voter was carrying out a public responsibility.

Commentators have sometimes queried whether Mill was really a 'public moralist' rather than a philosopher or a social scientist. ${ }^{39}$ But fundamental to Mill's philosophical work was the project of improving the world, and improving the world depended critically on challenging and recasting its morality. Varouxakis and Claeys have both shown just how important that moral project was in Mill's work.

${ }^{39}$ Frederick Rosen, Mill (Oxford, 2013), $79 .$. 